\title{
Correction to: CT volume of enhancement of disease (VED) can predict the early response to treatment and overall survival in patients with advanced HCC treated with sorafenib
}

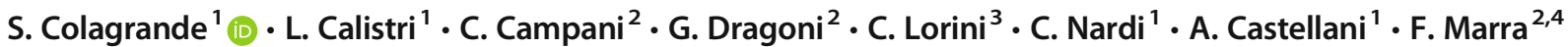

Published online: 15 December 2020

(C) The Author(s) 2020

\section{Correction to: European Radiology}

$$
\text { https://doi.org/10.1007/s00330-020-07171-3 }
$$

The original version of this article, published on 22 August 2020, unfortunately contained a mistake. The following correction has therefore been made in the original: The second equation in paragraph "VED calculation" was incorrect; the corrected equation is given below. The original article has been corrected.

$$
(\mathrm{V} 1 \times \Delta \mathrm{Art} \% 1+\mathrm{V} 2 \times \Delta \mathrm{Art} \% 2) /(\mathrm{V} 1+\mathrm{V} 2) \times 100
$$

Open Access This article is licensed under a Creative Commons Attribution 4.0 International License, which permits use, sharing, adaptation, distribution and reproduction in any medium or format, as long as you give appropriate credit to the original author(s) and the source, provide a link to the Creative Commons licence, and indicate if changes were made. The images or other third party material in this article are included in the article's Creative Commons licence, unless indicated otherwise in a credit line to the material. If material is not included in the article's Creative Commons licence and your intended use is not permitted by statutory regulation or exceeds the permitted use, you will need to obtain permission directly from the copyright holder. To view a copy of this licence, visit http://creativecommons.org/licenses/by/4.0/.

Publisher's note Springer Nature remains neutral with regard to jurisdictional claims in published maps and institutional affiliations.

The online version of the original article can be found at https://doi.org/ 10.1007/s00330-020-07171-3

S. Colagrande

stefano.colagrande@unifi.it

1 Department of Experimental and Clinical Biomedical Sciences, Radiodiagnostic Unit n. 2, University of Florence - Azienda Ospedaliero-Universitaria Careggi, Largo Brambilla 3, 50134 Florence, Italy

2 Department of Experimental and Clinical Medicine, University of Florence, 50134 Florence, Italy

3 Department of Health Science, University of Florence, Viale Morgagni 48, 50134 Florence, Italy

4 Research Centre Denothe, University of Florence, Florence, Italy 